\title{
Robotic spot welding of DOCOL 1200M steel
}

\author{
Jacek Górka1,** Andrzej Ozgowicz², Kamil Matusek ${ }^{1}$ \\ 1 Silesian University of Technology, Poland \\ 2 Stryvo AS, STRYN, Norway \\ Andrzej Ozgowicz; andrzej.ozgowicz@stryvo.no; \\ * Correspondence: Prof. Jacek Górka; jacek.gorka@polsl.pl
}

Received: 15.03.2019; Accepted: 30.03.2019

\begin{abstract}
The paper presents robotic spot resistance welding technologies for DOCOL 1200M steel with a thickness of $1.8 \mathrm{~mm}$. DOCOL $1200 \mathrm{M}$ steel with a martensitic structure is intended mainly for the production of car bumpers, side beams and other elements ensuring the safety of the user of motor vehicles. The test joints were made on a robotic station equipped with a KUKA KR180 robot and a welding from ARO. The obtained welded joints were subjected to macro and microscopic metallographic tests, hardness measurement and strength tests. It has been shown that for properly selected resistance spot welding, DOCOL $1200 \mathrm{M}$ steel joints with a satisfactory strength level can be obtained.
\end{abstract}

Keywords: DOCOL 1200M steel; spot welding; robotic welding; martensite

\section{Introduction}

The car industry is an important part of both the global and national economy. The increase in the revenue of this field directly affects the development of production technology, introducing innovations and investments in finding new materials from which individual car components are made. The current trend forces car manufacturers to reduce the weight of their cars. Responsibility for mass reduction lies mainly on the constructors of individual components and technologists responsible for the selection of materials. The cost of research related to materials and the requirement to reduce the weight of vehicles caused that manufacturers in the automotive sector are increasingly starting to reach for aluminum alloys, composites and steels with increased durability. The basic requirements set by the automotive sector towards the materials used are: the reduction of component weight while maintaining mechanical properties, the ability to absorb energy during collision, susceptibility to machining as well as good compliance for the creation of welded joints. In addition, it is important that the designed elements have a significant corrosion resistance and high fatigue strength. All technical aspects must go hand in hand with economics. For this reason, the most important thing is to find a balance between quality and the cost of manufacturing. In order to meet this demand of the automotive industry, Advanced High-Strength Steels (AHSS) were created. These materials proved to be successful in the production of vehicles due to three very important features: high tensile strength, up to $1700 \mathrm{MPa}$, yield strength, up to $1450 \mathrm{MPa}$ and A80 elongation, up to $30 \%$. It is also important that plastic processing and machining of these steels are relatively easy. The AHSS steels are often used in the automotive industry, because they give the possibility to reduce the thickness of car body plates and car body support elements, while increasing the mechanical properties in combination with conventional steels. An additional advantage of AHSS steel is the relatively low price, due to the small amount of alloy additives in steel $[1 \div 14]$.

\section{Own research}

The aim of the research was to determine the structure and properties of the lap joints of sheets with a thickness of $1.8 \mathrm{~mm}$ made of high-strength low-alloy steel DOCOL $1200 \mathrm{M}$, with a martensitic structure joined by a resistance spot welding technique. The actual chemical composition and properties of DOCOL $1200 \mathrm{M}$ steel are shown in Table I. 
Table I. The chemical composition and mechanical properties of martensitic DOCOL 1200M steel

\begin{tabular}{|c|c|c|c|c|c|c|c|c|c|c|c|}
\hline \multicolumn{12}{|c|}{ Concentration of elements, $\%$} \\
\hline $\mathrm{C}$ & Si & Mn & $\mathbf{P}$ & S & Al & $\mathrm{Nb}$ & $\mathbf{V}$ & $\mathbf{N i}$ & $\mathrm{Cr}$ & $\mathbf{N}$ & $\mathrm{Ce}^{*}$ \\
\hline 0.113 & 0.22 & 1.58 & 0.01 & 0.002 & 0.035 & 0.016 & 0.01 & 0.04 & 0.04 & 0.006 & 0.39 \\
\hline \multicolumn{12}{|c|}{ Mechanical properties } \\
\hline \multicolumn{4}{|c|}{ Tensile strength $R_{\mathrm{m}}, \mathrm{MPa}$} & & \multicolumn{4}{|c|}{ Yield strength $\mathrm{R}_{\mathrm{e}}, \mathrm{MPa}$} & \multicolumn{3}{|c|}{ Elongation $\mathrm{A}_{80}, \%$} \\
\hline \multicolumn{4}{|c|}{1260} & & \multicolumn{4}{|c|}{1060} & \multicolumn{3}{|c|}{5} \\
\hline
\end{tabular}

* Ce - carbon equivalent

\section{Welding process}

Test joints were made at a robotic station for spot resistance welding at ASKLA Machines \& Technologies. The KUKA KR180 robot was equipped with an ARO welding gun with servomechanisms ensuring optimal pressure of details, while the HARMS-WENDE controller ensured the stability of parameters throughout the entire welding cycle. Three single-bearing test joints were made. Two welds were made on each sample. Their location resulted directly from the available standards (PN-EN ISO 65202:2013-12, PN-EN ISO 15614-12:2014-09, PN-EN ISO 14554-1:2014-03, PN-EN ISO 14554-2:2014-03) and literature [15]. The methods of joining sheets are presented in figures 1 and 2. The parameters of the welding process are presented in Table II.

Table II. Parameters of the DOCOL 1200M sheet welding process

\begin{tabular}{cccccc}
\hline $\begin{array}{c}\text { Name } \\
\text { of the sample }\end{array}$ & $\begin{array}{c}\text { Clamping force } \\
{[\mathrm{kN}]}\end{array}$ & $\begin{array}{c}\text { Welding current } \\
\text { intensity [kA] }\end{array}$ & $\begin{array}{c}\text { Welding current } \\
\text { flow time [ms] }\end{array}$ & $\begin{array}{c}\text { Preheating current } \\
\text { flow time [ms] }\end{array}$ & $\begin{array}{c}\text { Preheating current } \\
\text { intensity [kA] }\end{array}$ \\
\hline A & 1,5 & 10 & 300 & 200 & 2 \\
\hline
\end{tabular}

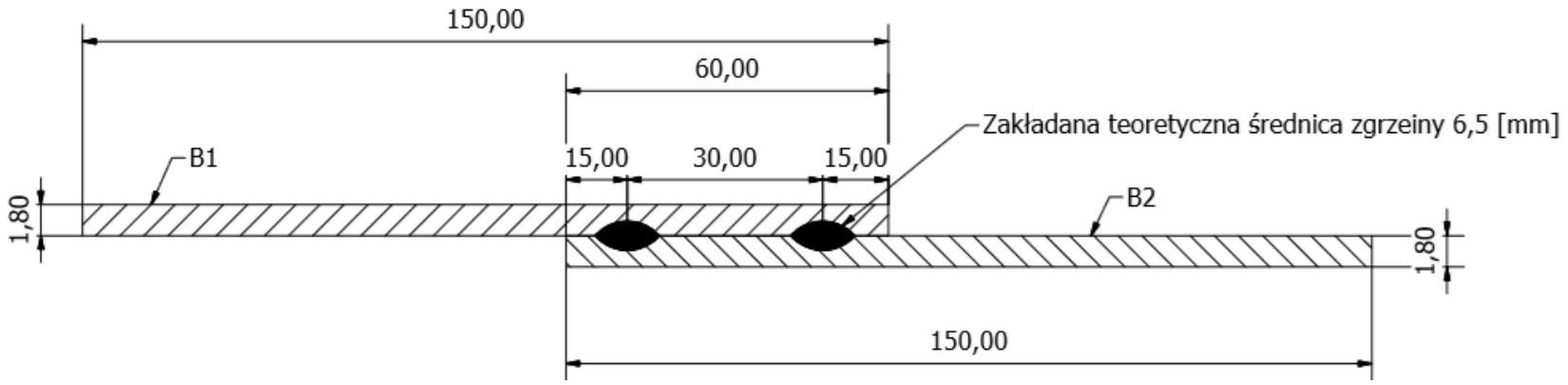

Fig. 1. Cross-section of a single-bearing joint for shear tests

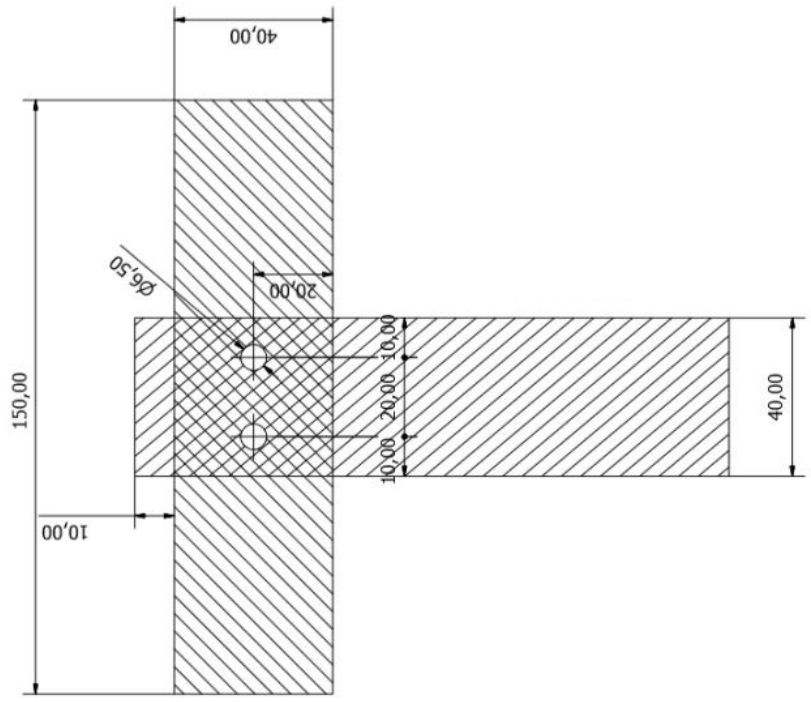

Fig. 2. Single-bearing joint for transverse tensile tests 


\section{Tests of the welded joints}

The welded joints have been subjected to:

- Macro- and microscopic metallographic examinations;

- A static shear test on the EDZ-20 testing machine in accordance with PN-EN ISO 14273:2016;

- Strength verification in accordance with PN-EN ISO 14273:2016;

- Vickers hardness measurement in accordance with PN-EN ISO 14271:2011.

\section{Analysis of the results}

The macroscopic examinations showed the correctness of the parameters used. No incompatibility was observed in the area of the welded joint, and the weld nugget is characterized by its correct shape and dimensions (Fig. 3).

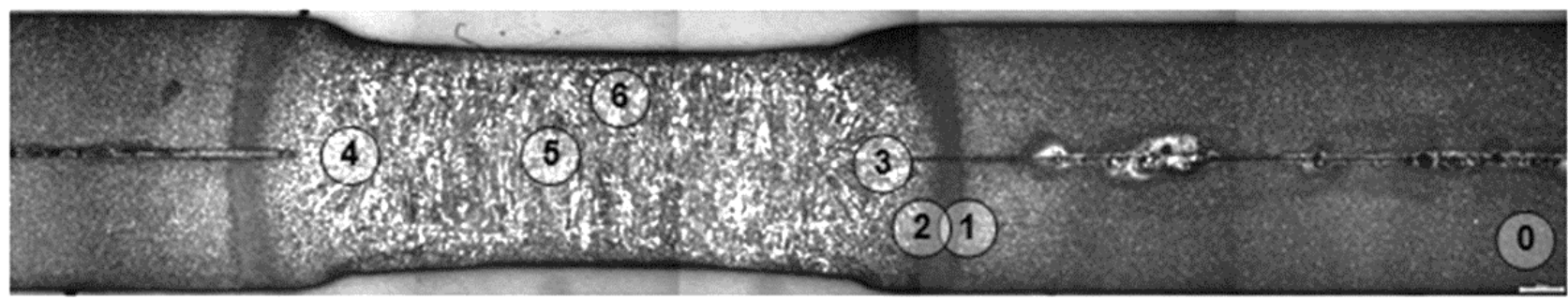

Fig. 3. Weld macrostructure with microscopic photo points marked

Metallographic microscopic examinations (Fig. 4) showed that in the heat affected zone preheated below the Ac1 temperature, the degree of martensite tempering increased with respect to the structure of the native material. In the area of preheating up to the temperature in the $A_{c} \div A_{c}$ range in the context of highly-dissolved martensite, the occurrence of islands with a martensitic or bainitic-martensitic structure was found. With the approaching of the weld and the increase in the volumetric temperature, the proportion of islands increases up to the complete recrystallization of the structure (exceeding the temperature of $\mathrm{Ac}_{3}$ ). In further areas of the HAZ an increase in the thickness of martensite needles is observed, which is related to the grain growth of the former austenite as the temperature rises. The weld has a bainitic-martensitic structure with a clearly marked columnar primary structure oriented towards the outflow of heat. In places where there was a positive segregation of carbon and manganese, a less intensely digesting belt with martensitic-bainitic structure was visible in the axis of the sheet. The occurrence of change in the morphology of the structure in this area is related to the shifting of critical cooling curves towards higher times as the concentration of dissolved elements in the austenite increases.

Strength calculations for the native material:

A sample of $1.8 \mathrm{~mm}$ in thickness and $40 \mathrm{~mm}$ in width was used for the tests - the surface of the samples was $72 \mathrm{~mm}^{2}$. Therefore, native material should transfer the minimum strength of:

$F_{\min }=72 \times 1200=86,4[\mathrm{kN}]=8.64[$ ton $]$.

Verification of strength of the welded joints:

It is assumed that the welded joint should transfer the force with a minimum value of $80 \%$ of the strength of the native material (in accordance with PN-EN ISO 14273: 2016) (Table III).

Table III. Results of the static shear test and checking the boundary conditions for welded joints

\begin{tabular}{ccc}
\hline No. of the sample & Shear force, $\mathbf{k N}$ & Strength of the native material \\
\hline A & $78,5(7,85$ ton $)$ & $86,4(8,64$ ton $)$ \\
\hline & $F_{\text {verification }}=\frac{78,5 \times 100}{86,4}=90,86 \%$
\end{tabular}

The joint meets the strength criteria

Vickers hardness measurements carried out confirmed the results of microscopic tests (Table IV). The area of the weld nugget is characterized by hardness above $400 \mathrm{HV} 0.1$, which corresponds to the martensitic structure. In the HAZ area, the martensitic structure of the native material is tempered (hardness at $400 \mathrm{HV0.1}$ ), as a result of which the hardness decreases to the level of $300 \mathrm{HV} 0.1$. 

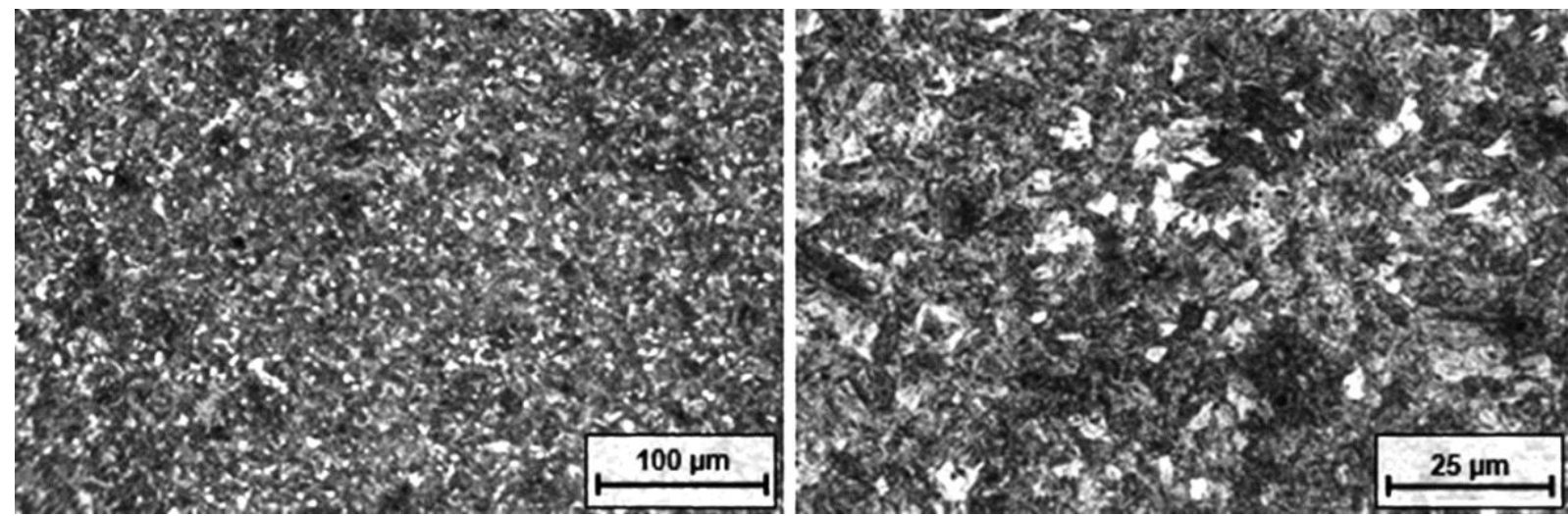

Point 0

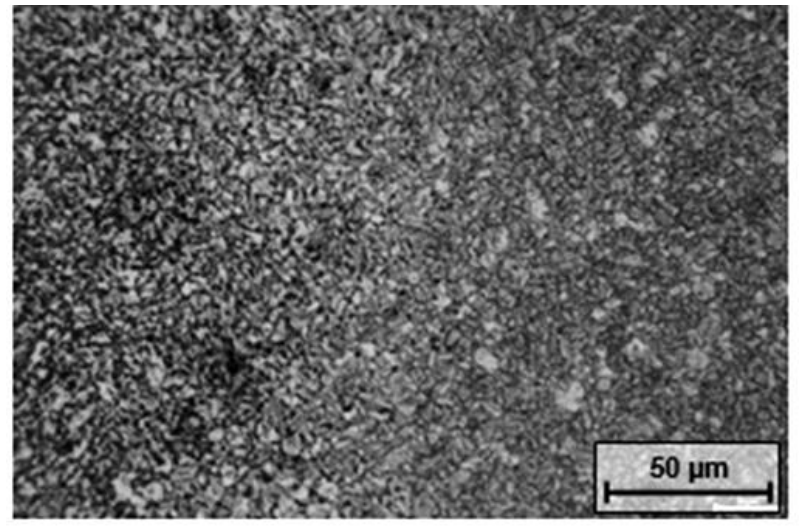

Point 1

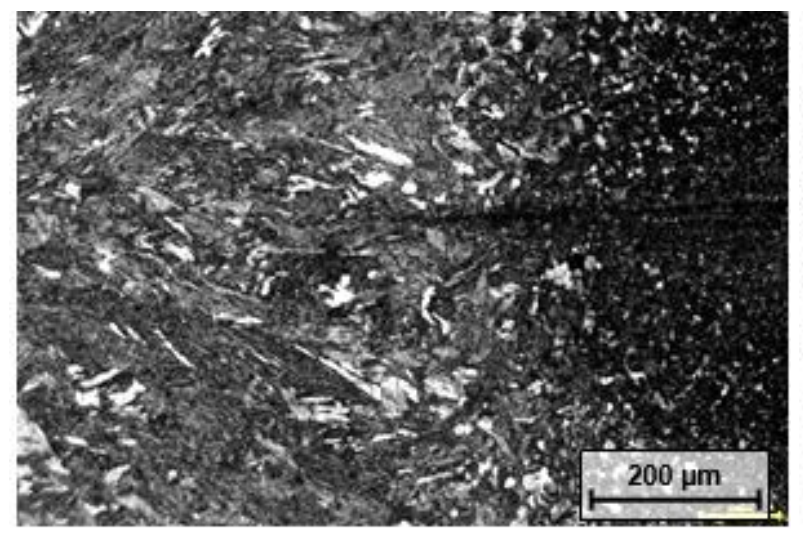

Point 3

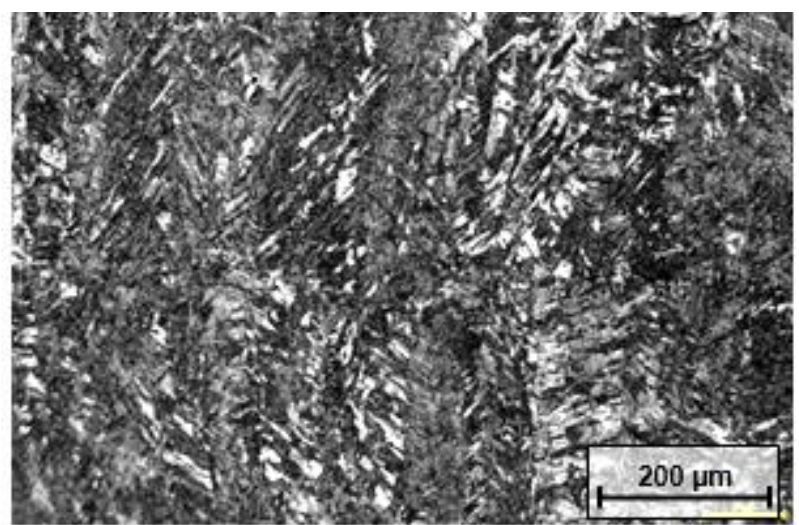

Point 5

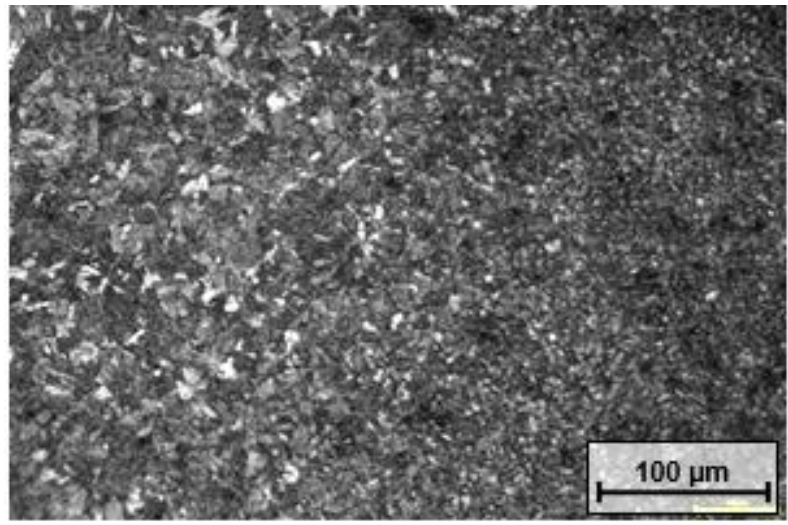

Point 2

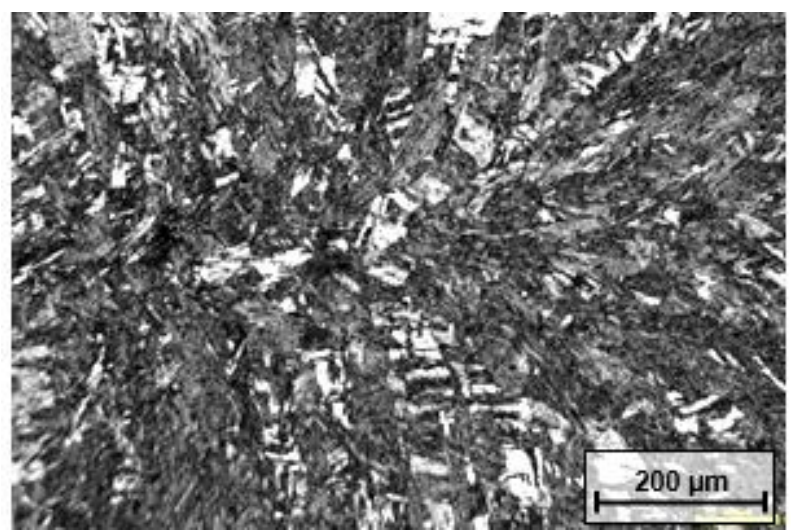

Point 4

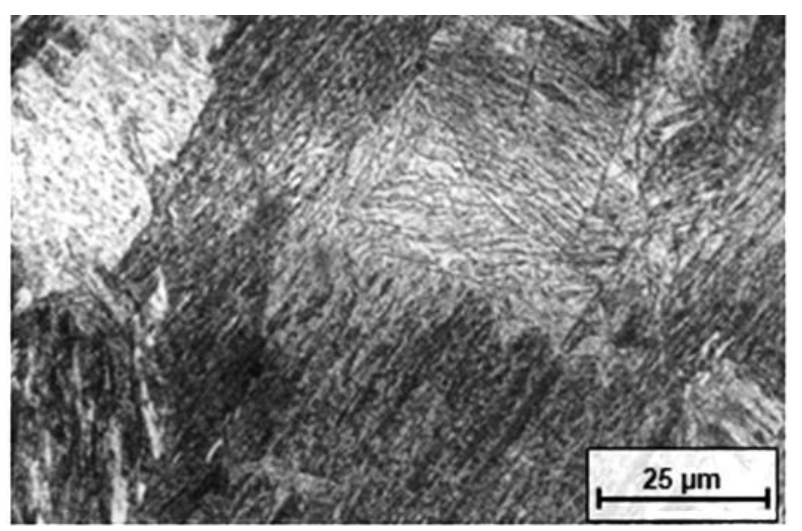

Point 6

Fig. 4. Microstructure of the welded joint 
Table IV. Hardness measurement microresults HV0.1

\begin{tabular}{cccc}
\hline $\begin{array}{c}\text { Measurement } \\
\text { number }\end{array}$ & Vertical measurement & Hordness HVo.1 & $\begin{array}{c}\text { Place } \\
\text { of measurement }\end{array}$ \\
\hline 1 & 368 & 428 & \\
2 & 383 & 390 & \\
3 & 400 & 402 & Weld nugget \\
4 & 418 & 382 & \\
5 & 376 & 392 & \\
6 & - & 415 & \\
7 & - & 418 & HAZ \\
8 & - & 390 & \\
9 & 321 & 306 & \\
10 & 335 & 388 & BM \\
11 & - & 403 & \\
12 & - & 414 & \\
13 & - & 398 & \\
14 & - & 414 & \\
15 & - & 398 & \\
\hline
\end{tabular}

\section{Conclusions}

Conducted tests of the resistance spot welding process of DOCOL $1200 \mathrm{M}$ steel with a thickness of $1.8 \mathrm{~mm}$, showed that it is possible to make welded joints that meet the functional requirements. Through appropriate selection of technological parameters, it is possible to obtain joints with the correct shape of the weld nugget and strength properties that meet the criteria in accordance with PN-EN ISO 14273:2016. The area of the weld nugget is characterized by a bainitic-martensitic structure with a clearly marked columnar primary structure oriented towards the outflow of heat. In HAZ, the native material was tempered, which resulted in the creation of a softened zone, with a hardness lower by approx. 100HV0.1 in relation to the native material.

\section{References}

1. Grajcar A., Różański M. Spawalność wysokowytrzymałych stali wielofazowych AHSS. Welding Technology Review 2014, vol. 86(3), 22-27. [CrossRef]

2. Flaxa V., Shaw J. Material applications in ULSAB-AVC. Steel Grips 2003, vol. 1(4), 255-261.

3. Krajewski S., Nowacki J. Mikrostruktura i właściwości stali o wysokiej wytrzymałości AHSS. Welding Technology Review 2011, vol. 83(7), 45-50. [CrossRef]

4. Stano S. Spawanie laserowe blach o zróżnicowanej grubości przeznaczonych na półfabrykaty karoserii samochodowych typu tailored blanks. Biuletyn Instytutu Spawalnictwa w Gliwicach 2005, vol. 2, 24-28.

5. Chen B., Yu H. Hot ductility behaviour of $\mathrm{V}-\mathrm{N}$ and $\mathrm{V}-\mathrm{Nb}$ microalloyed steels. International Journal of Minerals, Metallurgy and Materials 2012, vol. 19(6), 525. [CrossRef]

6. Żuk M., Górka J., Czupryński A., Adamiak M. Properties and structure of the weld joints of quench and tempered 4330V steel. Metalurgija 2016, vol. 55(4), 613-616. [Hyperlink]

7. Shipitsyn S., Babaskin Y., Kirchu I., Smolyakova L., Zolotar N., Microalloyed steel for railroad wheels. Steel in Translation 2008, vol. 38(9), 782-785. [CrossRef]

8. Godwin K., Yong O. Microstructure and fatigue performance of butt-welded joints in advanced high-strength steels. Materials Science \& Engineering 2014, A 597, 342-348. [CrossRef]

9. Siewer A., Krastel K. Fiber Laser Seam Stepper Replacing Resistance Spot-Welding. A cost-effective laser based tool to conventional welding technology, Laser Technik Journal 2014, vol. 4, 52-55. [CrossRef]

10. Górka J., Ozgowicz A., Próby spawania laserowego niskostopowej wysokowytrzymałej stali o strukturze martenzytycznej. Welding Technology Review 2016, vol. 88(5), 24-27. [CrossRef]

11. Senkara J., Współczesne stale karoseryjne dla przemysłu motoryzacyjnego i wytyczne technologiczne ich zgrzewania, Welding Technology Review 2009, vol. 81(11), 3-7.

12. Kaczmarek W., Panasiuk J., Zrobotyzowane procesy zgrzewania, Control Engineering 2015, vol. 5, 50-66. 
13. Zhang X.Y., Zhang Y.S., Chen G.L. Research on Weldability for Dual-Phase Steels Using Servo Gun Spot Welding System. Journal Key Engineering 2007, Material no 1597. [CrossRef]

14. Kowieski S., Mikno Z., Pietras A. Zgrzewanie nowoczesnych stali o wysokiej wytrzymałości. Biuletyn Instytutu Spawalnictwa w Gliwicach 2012, vol. 56(3), 46-51.

15. Poradnik inżyniera spawalnictwo, red. Jan Pilarczyk, Wydawnictwo Naukowe PWN, 2017.

(C) 2019 by the authors. Submitted for possible open access publication under the terms and conditions of the Creative Commons Attribution (CC BY) license (http://creativecommons.org/licenses/by/4.0/). 